\title{
A contraposição das noções de técnica e política nos discursos de uma elite burocrática
}

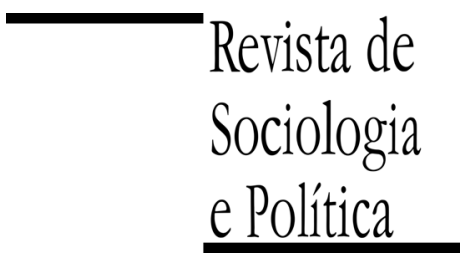

DOI 10.1590/1678-987315235505

\section{Elisa Klüger}

\section{Resumo}

O artigo faz uma análise comparativa da forma e do sentido da utilização e contraposição dos termos "técnica" e "política" nos discursos de dirigentes e funcionários do Banco Nacional de Desenvolvimento Econômico e Social, BNDE(S), em dois momentos: de 1952 ao início dos anos 1970 e de 1994 a 2011. A comparação foi feita através do exame de um conjunto de entrevistas realizadas nos anos 1980, com funcionários e dirigentes do primeiro período, e um segundo conjunto de entrevistas, feitas entre 2012 e 2014 , com diretores do segundo período. A análise dos dados permite ver que há uma transição do padrão dos discursos. Inicialmente havia uma oposição da burocracia aos políticos, que decorria da percepção de que haveria uma superioridade de uma burocracia qualificada para tomar decisões político-econômicas. No segundo período, posterior à redemocratização, o discurso expressa a tensão gerada pela necessidade simultânea de responder aos governantes titulares e de agir de modo a preservar os valores, a missão histórica do Banco e a excelência técnica contra ingerências políticas que pudessem ameaçar a instituição. Neste segundo momento não é o credenciamento dos burocratas e sim o refinamento das técnicas por eles empregadas que é mobilizado como recurso para justificar as decisões econômicas dos burocratas. As oposições encontradas foram lidas à luz das teorias críticas de Pierre Bourdieu e Herbert Marcuse, que permitem questionar o caráter meritocrático dos especialistas em Economia e a neutralidade da ciência e das técnicas por eles empregadas. O artigo contribui para o estudo das relações entre política e burocracia no Brasil através do estudo de um caso paradigmático. Ele permite verificar como a lógica da relação de oposição entre as esferas da técnica-ciência e da política se altera ao longo do tempo e busca, por meio de uma análise crítica dos dados, avaliar quais seriam os fundamentos sociais desta transformação.

PALAVRAS-CHAVE: BNDES; técnica; política; Pierre Bourdieu; Herbert Marcuse.

Recebido em 18 de Setembro de 2014. Aceito em 22 de Fevereiro de 2015.

\section{Introdução ${ }^{1}$}

\footnotetext{
1 Agradeço aos comentários e sugestões recebidos de Sylvia Garcia Gemignani, Maria Caramez Carlotto, dos organizadores do dossiê Cristiano Monteiro e Tomas Undurraga e dos pareceristas anônimos da Revista de Sociologia e Política.
}

2 O Banco Nacional de Desenvolvimento Econômico e Social adicionou o termo social e a letra $\mathrm{S}$ ao seu nome em 1982, quando o Banco passou a administrar o Finsocial: fundo destinado ao apoio de projetos de caráter
$66 \begin{aligned} & \text { peculiaridade da cultura moderna, especialmente a de sua base } \\ & \text { tecnico-econômica, exige precisamente esta "calculabilidade” do } \\ & \text { resultado. A burocracia em seu desenvolvimento pleno encon- }\end{aligned}$ tra-se, também, num sentido específico, sob o princípio sine ira ac studio. Ela desenvolve sua peculiaridade específica, bem-vinda ao capitalismo, com tanto maior perfeição quanto mais se "desumaniza", vale dizer, quanto mais perfeitamente consegue realizar aquela qualidade específica que é louvada como sua virtude: a eliminação do amor, do ódio e de todos os elementos sentimentais, puramente pessoais e, de modo geral, irracionais, que se subtraem ao cálculo, na execução das tarefas oficiais" (Weber 2004b, p.213).

As reflexões que serão desenvolvidas neste ensaio decorrem da comparação do modo como os termos técnica e política foram empregados nos discursos de dirigentes e funcionários do $\operatorname{BNDE}(\mathrm{S})^{2}$ em dois momentos históricos: a época de formação do Banco, dos anos 1950 aos anos 1970, e um período recente, 1994-2011. A passagem acima, extraída do segundo volume do livro Economia e Sociedade de Max Weber, servirá como baliza para a discussão que se pretende conduzir porquanto permite tecer considerações acerca dos fundamentos da oposição entre, de um lado, as noções de ciência e técnica e, de outro, 
social-assistencial. Ver Centro Celso Furtado (2009, p.316, p.339).

\footnotetext{
3 A análise dos discursos tem a intenção de expor como se contrapõem, nas falas dos funcionários e dirigentes da Banco, as noções de técnica e política. O texto não busca, de modo algum, avaliar a veracidade dos depoimentos ou oferecer respostas às questões endereçadas aos entrevistados.

4 Os discursos dos diretores do período recente provêm de uma série de entrevistas realizadas entre 2012 e 2014 com 39 dos 43 diretores que o banco teve no período 1994-2011 (eram 48 originalmente mas cinco faleceram antes do início da pesquisa). Já os depoimentos dos diretores e funcionários dos anos 1952 até os anos 1970 foram extraídos do volume três das Memórias do Desenvolvimento, publicação que reúne entrevistas feitas em 1982, na ocasião de comemoração de 30 anos do BNDE.
}

a noção de política. A análise dos discursos será concatenada com as meditações de Herbert Marcuse sobre a não neutralidade da ciência, das técnicas e da burocracia e com as asserções de Pierre Bourdieu acerca do caráter mágico do credenciamento e legitimação dos burocratas-especialistas que colabora para ocultar o caráter não universal de suas tomadas de posição. A partir das considerações críticas destes dois autores procurar-se-á enraizar social e historicamente os discursos ${ }^{3}$ sobre técnica e política proferidos pelos dirigentes e funcionários da instituição $0^{4}$.

Max Weber, nas conferências que dão origem ao volume Ciência e Política: duas vocações, procura delinear os limites que se teriam estabelecido entre as atividades científicas e administrativas e aquelas próprias à política nas sociedades modernas. Ele rejeita a ideia de que o conhecimento científico teria algo a dizer acerca do sentido do mundo: ou seja, sobre o que é verdadeiro, belo, desejável, sobre o modo como os humanos deveriam viver e agir; visto ser a ciência, precisamente, uma esfera a-religiosa. Caberia à política definir quais os princípios e os valores que deveriam mover a ação e restaria à ciência amparada nos dados, no cálculo, na probabilidade, em seus métodos, técnicas e na sua capacidade de identificar estruturas culturais - a tarefa de fazer previsões para determinar racionalmente a melhor forma de agir de acordo com objetivos que haveriam sido previamente elegidos na esfera política ${ }^{5}$ (Weber 2011, pp.45-46).

Sendo a ciência e a administração burocráticas meros instrumentos de previsão e execução de finalidades pré-determinadas, aqueles que delas se ocupassem deveriam conduzir suas atividades sem a interferência de sentimentos, valores ou preferências subjetivas, já que estes poderiam desviar sua ação dos rumos e ideais definidos na esfera pública. Para que fosse o mais racional possível, a burocracia deveria ser formada por um corpo de funcionários recrutados por concurso, cuja legitimidade estaria calcada em seu conhecimento técnico-especializado e em sua capacidade de empregar o cálculo para aumentar a aderência entre os meios e os fins. Weber diferencia os funcionários de carreira da burocracia dos funcionários "políticos", definidos como aqueles que podem ser deslocados à vontade e que são, em geral, substituídos quando há uma transição na gestão política do Estado. Ele afirma, entretanto, que também o funcionário político deveria isentar-se de fazer política, justamente porque sua vocação como burocrata seria a de administrar de forma não partidária em nome da razão de Estado (Weber 2004a, p.145; 2011, pp.73-74).

\section{BNDE(S): um locus privilegiado para a observação do uso dos termos técnica e política}

${ }^{5}$ A ação racional em relação a meios e fins tem um papel central no esquema de análise weberiano. Ela supõe que uma vez determinados os fins seria possível estabelecer de maneira racional quais meios poderiam conduzir, da melhor maneira possível, à finalidade desejada. A ação racional seria, portanto, compreensível, previsível e desencantada (Cohn 1979, p.83, pp.90-91).
Peter Evans, em seu livro Autonomia e parceria: estados e transformação industrial, caracteriza o Brasil como um caso intermediário entre um modelo "predatório" e um modelo "desenvolvimentista" de Estado. O primeiro seria regido fundamentalmente por uma lógica de lucro pessoal daqueles que ocupam as posições de poder e o segundo seria orientado primordialmente para o incentivo sistemático à transformação social e melhora das condições coletivas. Haveria no Brasil algumas instituições e burocracias que se assemelhariam àquelas existentes nos Estados "desenvolvimentistas": com funcionários altamente especializados, carreiras prestigiosas, bem conectadas aos setores estratégicos da sociedades e que, na área econômica, atuariam no sentido de viabilizar investimentos produtivos de longo-prazo, fornecendo capital e direcionando racionalmente a alocação dos recursos (Evans 1995, p.44-48).

Essas instituições, consideradas ilhas ou bolsões de excelência/eficiência na burocracia brasileira, teriam sido criadas com o intuito de escapar à lógica clientelista que prevaleceria na burocracia tradicional e nas arenas políticas. 
${ }^{6}$ A capacidade dos bolsões de eficiência para isolar-se da vida político-partidária varia de acordo com o tipo de regime político vigente, quanto mais democrático mais sujeito a pressões, com a força do governo, quanto mais apoio tiver menor será a necessidade de preencher cargos com base em critérios políticos e com o grau de favorecimento da instituição pelo governante titular (Geddes 1990).
Incapazes de transformar o conjunto do Estado, as forças capitalistas modernas criariam novos espaços, isolados da "irracionalidade" da vida política e das demandas populares, nos quais os técnicos teriam autonomia para tomar decisões racionalmente: planejar, financiar e implementar projetos, sobretudo nas áreas voltadas à produção econômica e à definição de políticas econômicas ${ }^{6}$. A Superintendência da Moeda e do Crédito (SUMOC), a Petrobrás, os Grupos Executivos de Juscelino Kubitschek, a Assessoria Econômica Vargas e o BNDE podem ser listados entre os primeiros organismos com essas características, tendo tido importante papel no processo de aprofundamento da industrialização brasileira a partir de meados do século XX (Geddes 1990, p.225; Gouvêa 1994, p.117; Evans 1995 p.61; Nunes 1984, pp.137-138).

Nos estudos de Geddes (1990), Schneider (1991), Nunes (1984), Martins (1985) e Evans (1995), publicados entre meados anos 1980 e meados dos anos 1990, o BNDE é apresentado como um dos principais bolsões de eficiência da burocracia brasileira e é contraposto ao mundo da política e da burocracia tradicional, considerada clientelista e ineficaz. Os estudos de Loureiro e Abrucio (1998) e Olivieri $(2007$; 2011) sobre a relação entre burocracia e política no período posterior à redemocratização retomam a premissa weberiana segundo a qual os organismos burocráticos deveriam responder às demandas oriundas da arena política em vez de se isolarem do controle democrático para fazer a política que considerarem mais adequada e eficiente. Eles indicam a necessidade de adotar uma perspectiva dinâmica e crítica na observação da interação entre as duas esferas, que não considere o que é técnico necessariamente como racional e o que é político necessariamente como corrompido. A estratégia por eles utilizada para analisar essa interação é observar os padrões de preenchimento dos cargos nos altos escalões de ministérios e do Banco Central para então detectar quais as lógicas que presidem a escolha daqueles que têm o poder de dirigir os organismos burocráticos.

Este artigo retorna ao $\mathrm{BNDE}(\mathrm{S})$, que guarda muitas das características de uma burocracia-modelo weberiana detectadas pelos estudos dos anos 19801990. Além disso, adota-se uma ferramenta distinta da observação dos padrões de preenchimento de cargos: fazer um exame histórico e crítico dos embates entre os deuses da ciência/técnica e aqueles da política que se desenrolam no âmbito da burocracia de Estado. A análise foi feita comparando-se os discursos sobre técnica e política recolhidos em entrevistas feitas com dirigentes e funcionários do $\mathrm{BNDE}(\mathrm{S})$ em dois momentos do tempo: o período de formação do Banco, de 1952 ao início dos anos 1970, que foi analisado nos estudos clássicos citados, e um período posterior à redemocratização, de 1994 até 2011.

A comparação histórica permite observar de que maneira o sentido da contraposição entre os termos técnica e política, as motivações subjacentes a ela e a sua intensidade transformam-se ao longo do tempo. O exame dos discursos torna visível a passagem de uma lógica de oposição à política e de superioridade da burocracia para tomar decisões econômicas - no período de formação do Banco - para uma dualidade na interação da burocracia com a política - na Nova República - que expressa a tensão frequentemente gerada pela necessidade simultânea de responder aos governantes titulares e de agir de acordo com os valores e ideais históricos da instituição.

A análise do sentido das tensões expressas na contraposição dos termos "técnica" e "política" será conduzida a partir das seguintes indagações críticas: em que medida é possível dissociar técnica e política na atuação de um especialista e economia? E quais seriam os possíveis fundamentos e efeitos sociais do discurso que conclama o caráter universal e politicamente neutro da técnica? 


\section{II.1 Características de uma burocracia modelo}

7 Promulgada em outubro de 2002, a última versão do Estatuto do Banco encontra-se disponível em: http://www.bndes.gov.br/Site BNDES/bndes/bndes_pt/Instit ucional/O_BNDES/Legislacao /estatuto_bndes.html. Acesso em 17 jun. 2015.

${ }^{8}$ O BNDE esteve vinculado primeiramente ao Ministério da Fazenda e depois à Secretaria de Planejamento da Presidência da República (Seplan).

${ }^{9}$ Habitualmente o Presidente da República escolhe o presidente do BNDES e este é responsável pela montagem da sua equipe, recrutando os outros dirigentes de acordo com seus projetos e predileções. É também usual que a diretoria mescle quadros provenientes do corpo de funcionários da instituição e profissionais recrutados externamente especialmente para ocupar a posição de diretor.

${ }^{10}$ Por exemplo, no grupo de entrevistados do período 1994-2011, 45\% dos diretores convidados concluíram o doutorado enquanto $31,25 \%$ dos diretores provenientes do corpo do Banco possuem o mesmo grau.
O Estatuto do BNDE(S) declara que o Banco deve submeter-se aos programas e desígnios dos políticos eleitos, o que está em consonância com a ideia weberiana de que a burocracia deve orientar seus trabalhos para satisfazer demandas políticas geradas externamente. Consta, nos artigos 1 e 3 do atual estatuto da instituição ${ }^{7}$, que o BNDES está sujeito à supervisão do Ministro do Desenvolvimento, Indústria e Comércio Exterior" e que o Banco é "o principal instrumento de execução da política de investimento do Governo Federal e tem por objetivo primordial apoiar programas, projetos, obras e serviços que se relacionem com o desenvolvimento econômico e social do País". O artigo 14 postula que a diretoria da instituição deverá ser nomeada pelo Presidente da República e que esta pode ser livremente demitida por ele ${ }^{9}$.

O Banco poderia, igualmente, ser caracterizado como uma burocracia exemplar no que concerne à sua política de recrutamento e gerenciamento de quadros. Os funcionários do $\mathrm{BNDE}(\mathrm{S})$ são recrutados por concurso, desde os anos 1950, e os diretores convidados para ocupar cargos na instituição - os funcionários "políticos" na denominação de Weber - são, em sua grande maioria, portadores de certificações de competências teóricas e técnicas ainda mais prestigiosas do que aquelas detidas pelos funcionários concursados ${ }^{10}$.

Via de regra, são convidados especialistas em Economia com uma produção acadêmica reconhecida e/ou com uma atuação de destaque em órgãos públicos e grupos privados. Eles são escolhidos de acordo com o conhecimento e a legitimidade que têm para desempenhar a função de condução da economia nacional, bem como pela amplitude de suas conexões no campo econômico, essenciais para conectar o Banco aos agentes econômicos.

Como no caso de outras agências centrais da área econômica: notavelmente o Banco Central, o Instituto de Pesquisa Econômica Aplicada (IPEA) e o Ministério da Fazenda, a escolha dos dirigentes do BNDE(S), em geral, não é usada como moeda de troca para obter apoio de outros grupos políticos. Tais cargos são distribuídos de acordo com escolhas estratégicas da administração central, que busca entregá-los a profissionais competentes, reconhecidos e que, ademais, estejam ideologicamente alinhados às prioridades do governo (Olivieri 2007, pp.147-149).

Finalmente, pode-se argumentar que o BNDES promove ativamente as habilidades de prever e calcular que Weber percebia como essenciais para a condução técnica da burocracia. Por um lado, o Banco estimula seus funcionários a desenvolver suas competências especializadas, baseando as promoções em mérito e incentivando-os a frequentar cursos de pós-graduação, de idiomas, seminários, colóquios, etc. Por outro lado, ele faz avançar a produção teórica e técnica em sua área de especialidade ao produzir diretamente ou financiar e publicar estudos, mapeamentos, revistas (BNDES em campo, BNDES setorial, Revista do BNDES), informes ("Informe BNDES", "Informe de finanças públicas e emprego", "Informes setoriais"), relatórios ("Relatórios semestrais de renda fixa", "Relatórios de investimento"), oferecer prêmios para teses de excelência em economia (Prêmio BNDES) e organizar seminários e debates, internos ou abertos ao público geral.

\section{II.2 Dissonâncias: a prática política de uma elite técnica}

Ainda que apresente uma série de características compatíveis com a concepção weberiana de burocracia, na fala dos diretores do BNDE(S) é possível detectar a existência de um conflito entre, por um lado, o ideal de burocracia técnica e desengajada e, por outro, o engajamento ativo do Banco na formulação 
de uma política de desenvolvimento para o país. Os dirigentes da instituição conclamam repetidamente o cultivo da técnica contra a política e ressaltam o caráter técnico de sua atuação. Frequentemente, no entanto, rejeitam a ideia de que o Banco deva ser uma simples máquina gerencial ou uma agência implementadora dos valores e decisões provenientes da vida política exterior, acreditando que ele pode e deve contribuir com a tarefa de formulação de planos e políticas.

Alguns tópicos aparecem repetidamente quando está em pauta a oposição entre o fazer técnico e o fazer político. O primeiro deles é a contraposição entre a noção de órgão de governo e aquela de órgão de Estado, que dá origem à seguinte reflexão: como instituição comprometida com o desenvolvimento e o avanço social do Estado brasileiro, o que seus quadros devem fazer quando julgam que as diretrizes do governo ou as ordens que emanam de algum político específico contradizem os valores e a missão essencial da instituição? O segundo é a crítica à falta de competência especializada dos políticos, que levaria os técnicos de alto escalão a acreditarem, algumas vezes, estar mais preparados para desenhar política econômica do que outros atores do governo.

O emprego do termo "político" nos discursos analisados ora designa aqueles que não possuem competências especializadas ora denomina aqueles que possuem a qualificação técnica mas que são acusados de ser francamente influenciados por ideais políticos. O discurso da competência predomina no período de fundação da instituição, o da neutralidade ganha força nas últimas décadas. As transformações no significado da oposição entre técnica e política não é fortuita e deve, portanto, ser descrita e analisada para que se possa compreender quais os processos e estruturas sociais subjacentes ao discursos.

\section{As visões de técnica e política no BNDE(S)}

\section{III.1 BNDE: pensar, definir, planejar, promover e executar o desenvolvimento}

${ }^{11}$ Os discursos utilizados nesse trecho provêm dos depoimentos de Lucas Lopes, Roberto Campos, Marcos Vianna, Celso Furtado, Maria da Conceição Tavares, Rômulo de Almeida, Sebastião Soares e Juvenal Osório. Seus depoimentos representam pontos de vista politicamente heterogêneos, posto que ocupam posições consideravelmente distantes no campo dos economistas. Ver o volume 3, número 3 do periódico Memórias do Desenvolvimento para maiores informações sobre suas trajetórias.

\footnotetext{
12 "Tanto é que a gente conseguiu trabalhar bem, com
}

É possível notar, desde o início, a ênfase nos discursos dos funcionários e diretores $^{11}$ do BNDE da ideia de que o corpo do Banco seria formado por técnicos de alta qualificação, selecionados por concurso e não politicamente, daí decorrendo seu prestígio, eficiência e objetividade para definir e julgar projetos.

\footnotetext{
"Ao tempo em que lá estive o BNDE era uma sementeira de técnicos respeitáveis que foram supridos a vários órgãos de governo. O BNDE se transformou no grande supridor de técnicos e técnicas para administração" (Campos 2009, p.64; presidente do BNDE).

"Durante todo esse período, o BNDE fez questão de selecionar o seu pessoal por mecanismo de concursos públicos, escolhendo o melhor técnico, evitando políticas pessoais na escolha dos seus técnicos" (Lopes 2009, p.29; presidente do BNDE).
}

A valorização da componente técnica, no entanto, não era acompanhada, nos primórdios da vida institucional, pela ideia de que as decisões tomadas por seus técnicos fossem ou devessem ser desprovidas de orientação política. Os quadros do Banco não acreditavam limitar sua função a acatar as orientações do governo e executá-las tecnicamente. Ao contrário, quase todos os depoimentos revelam a existência de repetidos conflitos entre o governo e o BNDE. A instituição lutava contra o governo para garantir seus recursos, para implementar suas diretrizes e para evitar ingerências provenientes das arenas propriamente políticas que, repetidas vezes, eram consideradas incompatíveis com a filosofia e missão da instituição. 
bastante liberdade, e conseguia impor nossos pontos de vista aos outros órgãos do governo, conseguia 'vender o peixe" (Osório 2009, pp.143-144; sem grifos no original). 13 "Ao fazer proselitismo em prol do desenvolvimento econômico na esfera privada, acabou formando o consenso de uma maioria a favor do desenvolvimento" (idem, p.154; sem grifos no original). 14 "Qual é o papel do Banco? É contribuir, de um lado, por meio do estudo, do debate, da formulação, para que $o$ governo e a própria sociedade brasileira encontrem esses novos caminhos" (Soares 2009, p.236; sem grifos no original).

15 "Como agência de desenvolvimento, procura qualificar, analisar e decidir sobre o interesse nacional da operação, ver se está enquadrada na estratégia nacional de desenvolvimento" (Vianna 2009, p.77; sem grifos no original).

16 "Havia decretos-leis que já saiam do Banco datilografados em papel da Presidência da República e não sofriam mudanças nem sequer de uma vírgula. Então, eram instrumentos de implantação de políticas produzidas no Banco que transitavam com a maior celeridade e fluidez na Presidência da República" (idem, p.73; sem grifos no original).
Expressões como "vender o peixe" ao governo ${ }^{12}$, "fazer proselitismo em nome do desenvolvimento" para "formar um consenso"13, "fazer com que o governo e a sociedade brasileira encontrem esses novos caminhos" 14 , "decidir sobre o interesse nacional"15 e "produzir políticas"16 mostram que havia um entendimento, por parte dos funcionários e dirigentes do BNDE, de que deveriam promover ativamente o que julgavam ser sua missão específica: desenvolver o país. No imaginário de seus quadros, o Banco não funcionava apenas como um órgão técnico que agia de acordo com os comandos que emanavam do governo, como representante eleito da população. No caso, os técnicos consideravam ser parte essencial de sua missão levar à esfera política definições acerca dos objetivos que deveriam ser perseguidos, traçar os planos de ação e, por fim, executá-los.

O único depoimento do período em que aparece claramente a ideia de que "O BNDE trabalhava apenas fornecendo pareceres técnicos aos ministros, às entidades, aos deputados, porque o BNDE não tinha função política" (Lopes 2009, p.15; sem grifos no original) é o do ex-presidente do Banco, Lucas Lopes. Poucas páginas depois, entretanto, o entrevistado se contradiz ao argumentar que o Banco "tem de ser mais restrito do que o foi. Eu não acho que o BNDE deva ser o órgão de formulação de política que foi naquela época" (idem, p.33; sem grifos no original). Ele revela, assim, entender que o papel do BNDE, no início, ultrapassava sim a elaboração de pareceres e execução técnica, englobando também a formulação de políticas.

Eles argumentam que, no primeiro período, o técnico negociava politicamente. Ele tentava pressionar os grupos de influência para que as decisões do governo, via diretoria, seguissem os ideais e projetos gestados no Banco (Tavares 2009, p.167). Um ex-presidente chega mesmo a relatar que adotava estratégias de blefe e manobra para que suas políticas fossem implementadas malgrado potenciais discordâncias ou desinteresse por parte do governo.

"Foi um período extremamente difícil, em que foi necessária certa dose de audácia irresponsável - ou quase irresponsável. Foi responsável porque deu certo! Mas era necessário fechar os comprometimentos a cada ano e comprometer-se a arrancar as decisões, mais ou menos na base do "blefe". Quer dizer, gerava-se o comprometimento e depois, com isso, estava assumido o compromisso de arrancar os recursos de qualquer maneira [...]. No momento em que houve um comprometimento com projetos absolutamente prioritários, o governo não tinha como não conceder os recursos" (Vianna 2009, p.72; Presidente BNDE).

É possível argumentar, portanto, que não era apenas com armas técnicas que lutavam os funcionários e dirigentes do Banco. Eles possuíam, além do prestígio acadêmico e profissional, laços com as elites políticas e econômicas locais e com instituições internacionais que funcionavam como trunfos nas lutas que travavam para definir e implementar um projeto de desenvolvimento.

Fizeram parte da equipe do BNDE alguns dos mais prestigiosos especialistas em Economia do período: Roberto Campos era um dos poucos diplomatas com formação em assuntos econômicos. Ele era formado em Economia pela George Washington University e havia realizado estudos de pós-graduação em Columbia, tendo participado da Comissão Mista Brasil-Estados Unidos (CMBEU) que deu origem ao BNDE (Campos 2009, p.46). Celso Furtado era advogado, havia trabalhado no Departamento Administrativo do Serviço Público (DASP). Ele tinha um doutorado concedido pela Faculdade de Direito e Ciências Econômicas da Sorbonne e, finalmente, era vinculado à já prestigiosa Comissão Econômica para a América Latina e o Caribe (Cepal) (Furtado 1997). Lucas Lopes também fizera parte da CMBEU. Ele era engenheiro e havia sido Ministro da Viação. Ainda em Minas Gerais, aproximou-se de Juscelino Kubitschek, alcançando posição de influência durante seu governo, no qual 
chegaria a ser nomeado Ministro da Fazenda, depois de ter sido presidente do BNDE. Rômulo de Almeida, Inácio Rangel e Cleantho de Paiva Leite, faziam parte da assessoria Econômica de Getúlio Vargas (D’Araujo 1992; Motta 2005). Marcos Vianna já havia sido diretor de grandes empresas e presidido o IPHAN antes de assumir a presidência do BNDES.

A mescla de valiosas conexões pessoais e políticas e de prestígio acadêmico e profissional permitia que esses funcionários e dirigentes agissem estrategicamente para tentar definir políticas e influenciar o governo. Cabe, portanto, dizer que o poder dos laços pessoais decorrentes da circulação burocrática e a capacidade de manejar as gramáticas personalistas da política (Nunes 1984, p.50-53; Schneider 1991, p.7) existentes no exterior do espaço insulado seguiam sendo recursos estratégicos, mesmo para aqueles que notabilizavam-se por seus atributos técnicos.

Nota-se, em diversos depoimentos, que o pleito por autonomia e a tentativa de salvaguardar a instituição chegaram a resultar em choques diretos com o governo. Em mais de um caso é mencionada a luta do BNDE contra governos e ministros que não o consideravam importante e que tentavam restringir seu orçamento e suas funções - sobretudo aqueles mais vinculados ao ideário (neo)liberal e à ideia de que o Brasil teria uma vocação agrária (Osório 2009, p.154; Vianna 2009, p.86). Por fim são mencionados casos em que houve conflito direto entre o governo e o BNDE resultando em negação frontal das diretrizes governamentais, consideradas pelos quadros do Banco parciais, enviesadas e, portanto, contrárias a orientação 'técnica' da instituição.

“Depois de um primeiro empréstimo, concedido em 1972, em 1974, ou 1975, a Lutfalla voltou a solicitar uma operação de crédito para saneamento do passivo. As primeiras observações, ainda na fase de prioridade, foram de que a Lutfalla não tinha seguido nenhuma das recomendações que o Banco havia feito quando da concessão do empréstimo original e estava numa situação de insolvência, não sendo, pois, recomendável o apoio do Banco. E o Banco foi chegando a essa conclusão ao longo do aprofundamento das análises. Ao mesmo tempo, foi sofrendo, não digo pressões, mas a presidência do Banco foi recebendo pedidos de diversas autoridades bem situadas argumentando que a Lutfalla não poderia quebrar. As análises do Banco foram concluindo e demonstrando que era totalmente impossível viabilizar a empresa com operação de financiamento [...]. Então o Banco decidiu que não podia conceder o financiamento. [...]. A empresa, que tinha acesso a instâncias políticas superiores do governo, procurou defender seus interesses. Por sua vez, o governo receou que se acelerasse um processo de deterioração do setor têxtil [...] decidiu, então, que não poderia haver a concordata ou a falência, e recomendou ao Banco que concedesse apoio à empresa. Recebi essa recomendação ao final da tarde e imediatamente reuni a diretoria do Banco. Disse que propunha, apesar da recomendação do governo, que o Banco mantivesse a sua decisão de não apoiar a empresa. A diretoria me apoiou por unanimidade. Foi uma reunião de 5 minutos, e foi redigido um telex ao governo. O conteúdo desse telex veio a público e dizia que apesar da recomendação do governo, a diretoria havia se reunido e decidido por unanimidade que não havia condições de o BNDE dar cumprimento a ela. Em reunião do Conselho Monetário, o governo acatou essa posição muito difícil e decidiu que, com recursos da reserva monetária, aportaria aqueles 350 milhões de cruzados à empresa, designando o Banco como executor, a risco zero" (Vianna 2009, pp.86-87).

Os relatos, que apontam para a existência de tensões entre as posições internas da instituição e aquelas dos governos vigentes, explicitam que o Banco tinha posições próprias, não se restringindo à tarefa de implementar decisões tomadas na vida política, como se esperaria de uma burocracia weberiana pura. A instituição havia cultivado um conjunto de valores próprios, um sentido de missão e um "espírito de corpo" que estavam na raiz de parte desses choques. O espírito de corpo do quadro técnico operava como um amálgama que repelia aqueles que ameaçavam a instituição e sua razão de ser (Furtado 2009, p.106). 
${ }^{17}$ Seus debates, muitas vezes, não se encerravam nos domínios do Banco já que os técnicos e diretores do $\mathrm{BNDE}(\mathrm{S})$ foram capazes de exercer influência nos debates políticos da vida nacional, seja através de sua produção teórica, seja por meio da participação em debates travados nos veículos de comunicação, seja através da atuação como consultores e conselheiros junto ao alto escalão político.
Por um lado, o Banco reivindicava a técnica contra a política tradicional, por outro lado, não entendia sua função como apolítica, com efeito, internamente discutia-se política com entusiasmo e regularidade ${ }^{17}$. O BNDE congregava técnicos com uma grande pluralidade de visões políticas, de economia e de desenvolvimento, o que dava origem a uma série de discussões acaloradas sobre as rumos e prioridades que deveriam ser adotados pelo Banco: empresa nacional versus empresa estrangeira, indústria básica versus indústria leve, foram, por exemplo, alguns dos mais importantes debates do primeiro período (Osório 2009, p.143).

Se os técnicos tinham ideologias próprias, definiam políticas, tentavam influenciar o governo, acreditavam ser legítimo discordar do governo quando consideravam que este estava errado; a negação em seus discursos daquilo que é político não se devia a uma crença no caráter puramente técnico de suas funções. O que explicaria, então, a oposição entre os termos técnica e política nos seguintes relatos?

"Eu, por exemplo, fui diretor pouco mais de um ano, na primeira fase, depois pedi exoneração. Assim também ocorreu com o Dr. Glycon Paiva, porque sentimos um começo de interferência política nas decisões do BNDE. Naquele tempo, nós dois éramos tecnocratas puristas e não admitíamos ingerência política, e o presidente Vargas tinha suas prioridades políticas que não se compaginavam com as ideias, talvez ingênuas, dos tecnocratas. Glycon de Paiva e eu renunciamos ao mandato porque acreditávamos que se devia manter um purismo técnico nas decisões do Banco, sem a condimentação política que o presidente Vargas, ou talvez menos o presidente Vargas do que agentes falando em seu nome, queria imprimir ao Banco" (Campos 2009, p.46; Diretor do BNDE).

"Getúlio tenta um compromisso e faz uma diretoria complicada, isto é, põe Campos como diretor e, ao mesmo tempo, como superintendente, Maciel Filho, que não tinha nada a ver com o espírito daquele grupo que pensava o desenvolvimento. Ele era um homem que vinha do Rio Grande do Sul, ligado aos interesses mais diretos do grupo Vargas, que podiam ser legítimos e indispensáveis, mas nada tinham a ver com o desenvolvimento e as técnicas que se exigiam, nem com, como se dizia, o espírito novo que era como que a matriz do espírito tecnocrata que emergia" (Furtado 2009, p.106; Diretor BNDE).

É possível sustentar que o que rejeitavam não era propriamente que o Banco tivesse orientações políticas e que estas funcionassem como balizas para a definição de um projeto de país - que é o que muitos consideram estar em jogo em uma instituição de alto escalão do Estado com potencial financeiro e instrumentos para desenhar políticas e transformar a economia e a sociedade. $\mathrm{O}$ conflito primordial expresso na oposição dos termos "técnica" e "política", neste caso, decorre da contraposição entre os técnicos modernos e os políticos tradicionais, desprovidos de certificações e de competências especializadas, que os técnicos consideravam fundamentais para fazer política de maneira racional. Eles buscavam realçar a falta de "vivência técnica" (Campos 2009, p.47), o despreparo para julgar o "mérito intrínseco dos projetos" (Lopes 2009, p.28) chegando até mesmo a falar em "irracionalidade temperamental" (Campos 2009, p.54) dos políticos. Um político ou homem de confiança de um político não estaria portanto, no juízo destes técnicos, apto a presidir uma instituição especializada, não sendo capaz tomar decisões políticas ou técnicas fundadas na razão.

As oposições entre os ditos técnicos e os ditos políticos trata-se, neste caso, antes de uma defesa do território no qual os técnicos fazem valer suas credenciais especializadas e de uma declaração da maior capacidade dos técnicos para fazer a política do que de uma apologia à cisão entre a técnica e a política, como esferas regidas por lógicas distintas que deveriam prestar-se a tarefas não equivalentes. Seguindo esse raciocínio, haveria uma busca pela racionalização 
da política e uma reivindicação de que também a política fosse feita por aqueles que detêm competências de natureza técnico-científica (Klüger 2014, p.79). Essa oposição também reflete a tentativa dos técnicos de insular-se das lógicas políticas clientelistas vigentes nas arenas políticas centrais, por eles percebidas como fonte do atraso social com o qual se chocavam (Nunes 1984, p.118).

Nesse ponto há uma ruptura nítida com o ideal de separação das esferas preconizado por Weber. A ciência e a técnica apresentam-se como a chave para fazer a política e não como meras ferramentas para a adequação técnica dos meios a fins que lhe são externos. A política feita como ciência, pode, assim, apresentar-se como racionalmente orientada e neutra. As finalidades e pressupostos que estão em sua origem deixam de caber à discussão dos não qualificados para restringir-se às arenas de técnicos, como se a própria política nada mais fosse do que uma alocação eficiente de recursos.

\section{III.2 BNDES: executar os planos do governo com eficiência}

Antes de introduzir os discursos dos dirigentes das últimas décadas serão apresentadas algumas considerações feitas pelos entrevistados do primeiro período acerca das mudanças que observavam estar ocorrendo na instituição entre os dois tempos. Eles afirmam ter havido uma passagem de uma fase na qual a instituição tinha uma orientação política explícita e uma maior liberdade para definir políticas para uma configuração na qual vigeria uma lógica fundamentalmente gerencial e na qual a haveria menor autonomia na condução da instituição.

"Na revista, os técnicos do banco assinavam com nome e apellido, criticando a política do governo, ao qual eles pertenciam. E não acontecia nada, ninguém perdeu o emprego. [...]. Se hoje um diretor do Banco assinar com nome e apellido contra o Langoni, o mais provável é que caia. Não é verdade? Pois é! Essa era a diferença" (Tavares 2009, p.171; funcionária do BNDE; sem grifos no original).

"O técnico que ingressa no Banco hoje pensa que lá está tudo definido, e bem definido. Então, ele será uma peça dentro daquela máquina para exercer determinada função específica, e nada além daquilo. [...] O grande risco que eu vejo é este, dos técnicos novos não saberem que a máquina não é boa, e que ela não foi programada para exercer determinada função, ela não tem inteligência. É preciso superar isso continuamente, dando diretrizes para a máquina funcionar" (Osório 2009, p.159; Funcionário BNDE; sem grifos no original).

"Uma outra crítica que eu faria ao BNDE, que é muito similar à primeira, é que não tomou a iniciativa de propor coisas [...] porque o BNDE ficou muito preocupado com sua eficiência como empresa e chegou até a pontos ridículos em certas administrações" (Almeida 2009, p.205; funcionário do BNDE; sem grifos no original).

Os depoimentos coletados no período recente reforçam o diagnóstico de que haveria um foco na eficiência da instituição para implementar as políticas governamentais, independentemente de quais fossem, e uma reiteração do caráter técnico das tomadas de decisão da instituição em detrimento da premissa recorrentemente aceita no primeiro período de que o órgão burocrático poderia e deveria pensar e ajudar a definir a política $^{18}$.

despolitização do Banco, poderiam ser atribuídas à consolidação das ferramentas de análise de projetos. Se antes se dizia: "análise este projeto" e então o técnico tinha que pensar em como resolver esse problema, atualmente haveria um

A observação das alterações no emprego dos termos técnica e política nos discursos ${ }^{19}$ dos dirigentes que a instituição teve no período 1994-2011 será conduzida a partir da análise das respostas às seguintes perguntas presentes no roteiro das entrevistas ${ }^{20}$ :

(i) Qual o(a) senhor(a) considera ser o papel do BNDES na construção/condução de uma política de desenvolvimento? 
conjunto de parâmetros e métodos estabelecidos para analisar os projetos: "faça este quadro de Usos e Fontes" (SOARES 2009, pp.212-213).

19 As respostas dos entrevistados não serão identificadas. Apenas serão incluídas respostas consideradas ilustrativas de cada uma das posições presentes no conjunto das entrevistas. Foram removidos dos trechos citados informações que poderiam identificar os entrevistados, marcadores de hesitações e repetições de palavras.

${ }^{20}$ Comentários sobre esses temas feitos em outros momentos da entrevista sem o estímulo do entrevistador também são utilizados na análise. (ii) $\mathrm{O}$ (a) senhor(a) acredita que o BNDES tem uma relativa autonomia em relação ao governo para tomar suas decisões?

(iii) $\mathrm{O}$ (a) senhor(a) concorda com a afirmação de que o BNDES teria um forte espírito de corpo?

Ainda que, em linhas gerais, haja uma difusão da crença de que a instituição deveria primordialmente executar - de maneira eficiente - as políticas encomendadas pelo governo, subsistem ressalvas e críticas a essa diretriz as quais provocam tensões internas e motivam conflitos com agentes externos à instituição. Para compreender tais disputas institucionais é primordial recordar que o segundo período coincide com a fase de consolidação da Nova República, marcada por uma multiplicação partidária e pelo retorno de uma lógica estratégica de alocação de cargos e recursos dentro de um jogo político-partidário, que ecoa as disputas entre os grupos e interesses presentes na sociedade.

Uma segunda transformação estrutural decorre da ampliação e do fracionamento do campo dos especialistas em economia. Se no primeiro período a contraposição entre técnicos e políticos prevalecia em relação a disputas entre os próprios especialistas em economia, no segundo período, há notável competição entre economistas provenientes de pontos dissimilares em um campo no qual as oposições entre escolas com filosofias político-econômicas distintas tornaram-se mais nítidas. Governos diferentes acabaram por recrutar profissionais provenientes de diferentes polos do campo de acordo com suas ideologias e prioridades.

A disputa que será analisada neste artigo, entretanto, não se refere aos ideários de cada governo e de seus economistas, mas ao tipo e grau de autonomia da burocracia em relação à vida político-partidária em cada período ${ }^{21}$. Prevalecem, pois, contraposições entre diferentes visões de quais seriam as atribuições de um órgão burocrático especializado em meio ao universo político democrático. Essas visões são influenciadas pelas modalidades de trajetórias (fundamentalmente de Estado, de mercado ou acadêmica) ${ }^{22}$, pelas formas de ingresso na instituição (funcionário de carreira ou diretor convidado) ${ }^{23}$ e pelo tipo de vínculo que possuem com os partidos políticos ${ }^{24}$. Tais informações constarão após os trechos de depoimentos citados com o objetivo de posicionar as falas no interior dessa estrutura de oposições ${ }^{25}$.

\section{III.2.1 Órgão de Governo elou órgão de Estado?}

${ }^{21}$ Um artigo relacionando os perfis e as trajetórias dos dirigentes do Banco às visões econômicas prevalecentes nos discursos recolhidos nas entrevistas está em elaboração. A polarização dos discursos detectada neste artigo tem suas principais raízes nas posições ocupadas no campo dos economistas e no campo do poder.

22 O cálculo do tipo de trajetória é feito somando-se o número de anos que o dirigente esteve ocupado em cada um dos setores entre o momento de conclusão da graduação e a entrada na diretoria, extraindo-se o percentual correspondente a cada tipo de vinculação. Se a pessoa teve vínculos
“O BNDES não é um órgão de governo. É outra questão. Como Forças Armadas, como o Itamaraty, etc. tem que ter uma postura de Estado. Então para isso tem que ter autonomia em relação ao governo. Não total, mas relativa autonomia. Nada é totalmente autônomo quando tem governo"26.

"Eu acho que o BNDES poderia ser incluído como o que a gente chama de uma instituição do Estado Brasileiro. Como as Forças Armadas, o Banco Central, o Itamaraty. Acho que o BNDES estaria incluído aí e, embora siga políticas de governo, ele tem bastante autonomia decisória. Dificilmente alguém conseguia fazer com que o BNDES tomasse uma decisão que não tivesse amparada em um parecer técnico" 27 .

Alguns diretores argumentam que o BNDES - tal qual as Forças Armadas e o Itamaraty - é um órgão que tem um compromisso primordial com o Estado e não com o governo de ocasião. Eles consideram que o BNDES teria constituído, ao longo de sua história, um conjunto de valores, tradições e uma missão própria: desenvolver o país, que não deveria estar vulnerável à volatilidade provocada pelas alterações de governo. Essa visão é especialmente recorrente entre funcionários de carreira sem filiação partidária ${ }^{28}$ que são aqueles que possuem os laços mais fortes e duradouros com a instituição e seus ideais. 
concomitantes o ano será somado a mais de um setor.

${ }^{23}$ Forma de ingresso no

Banco.

${ }^{24}$ Se já teve alguma filiação partidária.

${ }^{25}$ O grupo de entrevistados é composto por 25 pessoas que ocuparam a diretoria no governo PSDB e 15 pessoas que ocuparam o mesmo posto no governo PT (sendo que uma pessoa atuou em ambos). Isso aumenta a chance de que a fala mais representativa sobre o tópico seja de alguém que atuou no período PSDB.

${ }^{26}$ Entrevista. Diretor que havia sido funcionário de carreira do Banco e que foi diretor no governo PT carreira composta por $61 \%$ Estado, 0\% mercado e $39 \%$ academia. Sem filiação político-partidária.

27 Entrevista. Diretor que havia sido funcionário de carreira do Banco e que foi diretor no governo PSDB carreira composta por $68 \%$ Estado, 0\% mercado e $32 \%$ academia. Sem filiação político-partidária.

28 Nenhum dos diretores de carreira citados tem filiação partidária, os diretores convidados, em contraste, repartem-se entre os que tem filiação partidária e os que não tem.

29 Entrevista. Diretor que havia sido funcionário de carreira do Banco e que foi diretor no governo PT carreira composta por $82 \%$ Estado, $12 \%$ mercado e $6 \%$ na academia. Sem filiação político-partidária.

${ }^{30}$ Entrevista. Especialista convidado para fazer parte da diretoria do Banco no governo PT - carreira composta por $24 \%$ Estado, $0 \%$ mercado e $76 \%$ na academia. Com filiação político-partidária.
$\mathrm{O}$ vínculo com o governo e a adesão às diretrizes de governo não são rejeitados, mas argumenta-se que é preciso manter uma relativa autonomia que permita ao Banco blindar-se contra pressões políticas que poderiam provocar desvios da missão primordial da instituição. A questão suscitada pelos defensores da ideia de que o BNDES seria um órgão de Estado é: como agir quando se crê que a dinâmica partidária estaria ameaçando aquilo que consideram ser interesses de Estado e desviando o Banco de sua missão?

Na maior parte das entrevistas desse período, contudo, a lealdade ao Estado e a lealdade ao governo não são contrapostas diretamente nem pelos diretores de carreira nem pelos especialistas convidados; nem pelos diretores filiados nem pelos independentes, não importando o tipo de trajetória que tenham percorrido. Grande parte dos entrevistados consideram que o Banco não é autônomo e que, por ser um instrumento de governo, ele deve ajustar-se aos desígnios e prioridades da gestão eleita: mais petroquímica, mais privatização, mais estatização, mais infraestrutura, mais inovação etc.

"Eu acho que o papel do BNDES é ajudar a realizar políticas de governo. Então, conforme vão mudando os governos e os momentos esse papel do BNDES também tem que se adaptar. Ele já foi em um certa época um instrumento do governo para promover a privatização, depois para promover o investimento na infraestrutura. Então ele é uma instituição que se adapta, ao longo do tempo, às necessidades daquela época, daquele momento econômico e do momento político também"29.

"O BNDES é o ator na área de desenvolvimento e a agenda de desenvolvimento toda hora tem novidades. O BNDES tem que procurar atender a agenda de desenvolvimento do governo, agora, o governo deixa claro qual que é a melhor forma de atuação. O governo deixa claro o que é que ele quer do BNDES e o BNDES tenta executar da forma mais eficiente e correta possível. Certo? Então, na forma de executar a agenda do governo o BNDES tem de ter autonomia. Assim, ele tem que ter uma certa autonomia operacional" 30 .

Prevalece, neste momento, o discurso de que as políticas recomendadas pelo governo devem ser implementadas desde que aprovadas de acordo com as normas técnicas criadas pela instituição para analisar e selecionar projetos. A resistência do BNDES às pressões políticas não desvanece, ela muda de forma. Em uma democracia em processo de consolidação, não se afirma mais haver uma superioridade dos técnicos para elaborar a política, já que reconhecem ser o Banco um instrumento necessariamente engajado na execução das políticas federais dos governos eleitos, mas reivindica-se liberdade para avaliar se os projetos são bons e viáveis de acordo com critérios técnicos rigorosos e padronizados, estabelecidos internamente. Para os entrevistados oriundos dos mais diversos setores seria precisamente neste ponto que residiria a autonomia da instituição.

"O Banco é uma burocracia organizada que dispõe de mecanismos de proteção. Por exemplo, o processo de tomada de decisão no banco é um processo complexo. Entra lá um pedido. Necessariamente tem que entrar um pedido. Sem um pedido não existe. Entra, vai ser examinado por um departamento de prioridades. Eles dão lá a sua opinião sobre o projeto que vai para um corpo de superintendentes, chamado comitê de prioridades, que decidem se aquilo vai ser jogado para frente ou não. Ou se vai ser levado com modificações ou não. Aí dá-se se um prazo para devolver o projeto. Vai ser analisado numa área que tem lá um grupo que tem três ou quatro pessoas, tem um chefe, um superintendente. Aí manda para um diretoria que tem sete ou oito membros [...]. É uma burocracia organizada mas não é autônoma de forma nenhuma. Primeiro, em relação a uma coisa importante, é totalmente dependente do DS lá de Brasília: 'faz isso, não faz aquilo'. O Governo Federal, como o dono do banco, evidente né, tem a capacidade de pedir para o Banco formular programas. Então ainda que o Banco ache que aquele programa não é prioritário, ele tem que fazer aquele programa. 
31 Entrevista. Diretor que havia sido funcionário de carreira do Banco e que foi diretor no governo PSDB carreira composta por $90 \%$ Estado, $7 \%$ mercado e 3\% academia. Sem filiação político-partidária.

${ }^{32}$ Entrevista. Especialista convidado para fazer parte da diretoria do Banco no governo PSDB - carreira composta por $53 \%$ Estado, $0 \%$ mercado e $47 \%$ academia. Sem filiação político-partidária.

${ }^{33}$ Entrevista. Especialista convidado para fazer parte da diretoria do Banco no governo PSDB - carreira composta por $0 \%$ Estado, $100 \%$ mercado e $0 \%$ academia. Sem filiação político-partidária.

\footnotetext{
${ }^{34}$ Entrevista. Especialista convidado para fazer parte da diretoria do Banco no governo PT - carreira composta por $9 \%$ Estado, $31 \%$ mercado e $60 \%$ na academia. Com filiação político-partidária.
}

Evidentemente ele só vai financiar dentro daquele programa o que ele acha que deva e possa ser financiado" 31 .

"Assim, o que eu acho é que apesar de eu falar: olha, é o principal instrumento de política econômica, não dá para mexer no BNDES. Ele não é uma coisa maleável. Então, nesse sentido, e eu acho que é um dado positivo. Entendeu? Quer dizer, ele tem lá os seus ritos, as suas lógicas. Claro, aí cabe à diretoria definir novas frentes e criar novas políticas. Quer dizer, o BNDES é altamente institucionalizado [...] Ele é by the book. Você quer criar um programa de financiar rodapé. Não existe antes. Não adianta fazer um projeto de rodapé. Então escreve um programa de financiamento de rodapé. Apresenta na diretoria e você vai financiar todos os rodapés do Brasil" 32 .

"Eu não vi nenhuma decisão, enquanto nós estávamos lá, que tenha sido tomada por razões de influência de pessoa A, B ou C. Esse setor do governo vs. aquele setor do governo. Foi tomada a decisão porque o projeto era bom, o projeto não era bom. Fez isso ou deixou de fazer aquilo por razões econômicas, por razões de crédito[...], tudo precisa de um parecer técnico, tudo precisa de uma análise de crédito, tudo precisa estar dentro das regras do Banco. E quando não está, a máquina é muito eficaz em proteger o Banco. Por isso, aliás, eu diria que o Banco, com toda as décadas de história, tem sobrevivido como um centro de excelência, assim como uma organização que se manteve bastante alheia às pressões políticas" ${ }^{33}$.

Não são mencionados, neste período, casos de confrontos com o governo que tenham sido resolvidos em favor do BNDES. Nas poucas ocasiões em que algum diretor indispôs-se abertamente com o governo, o dirigente do Banco acabou sendo substituído. Tal qual havia previsto Maria da Conceição Tavares, atualmente, se alguém opõe-se publicamente ao ministro o mais provável é que caia. O BNDES é uma instituição prestigiosa e amplamente dotada de recursos. Seu poder é, muitas vezes, comparado ao de um ministério mas sua posição na hierarquia é subordinada aos níveis presidencial e ministerial, devendo ele, portanto, seguir os desígnios dos representantes democraticamente eleitos. $\mathrm{O}$ dirigente hábil, neste período, é aquele que consegue ser ouvido pelos políticos que ocupam as posições hierarquicamente superiores e que sabe apresentar e defender as suas propostas sem ameaçar o equilíbrio das estruturas. Um dos entrevistados comenta ter dito a um político:

“O BNDES está no terceiro escalão. Nós somos assim como os seus ajudantes de ordens. Ele falou [o Presidente do Brasil]: não, também não precisa exagerar tanto! É, mas obviamente a gente tem que considerar que [...] quem tem o mandato popular para fazer as grandes escolhas é o chefe do executivo e os seus ministros, [aqueles] a quem ele delegou isso. Mas isso não exime o Banco de ter um planejamento e uma estratégia coorporativa de longo prazo" ${ }^{34}$.

A tendência já observada nos intermediários anos 1980, de uma maior aderência ao governo, parece, pois, acentuar-se no segundo período analisado. A redução da autonomia da instituição para tomar decisões pode ser vinculada a um processo de enquadramento das estruturas institucionais da área econômica e de subordinação de seus técnicos aos representantes eleitos. $\mathrm{O}$ aumento do número de especialistas em economia colabora para que haja maior difusão do poder dos economistas antes concentrado em um reduzido número de figuras. Se no período de formação do Banco os especialistas em economia eram poucos e tinham muita influência, o aumento do número de profissionais faz com que raramente alguém, pela excepcionalidade de suas credenciais, acumule força desproporcional para propor e decidir - poder que tiveram no passado especialistas como Roberto Campos, Celso Furtado ou Lucas Lopes.

A autonomia da instituição no período atual é entendida, portanto, como sendo antes operacional do que política. Ainda que deva executar as políticas delineadas pelo governo, o Banco teria autonomia para implementá-las seguindo procedimentos próprios e padronizados. Estes seriam os responsáveis 
por garantir que os financiamentos fossem concedidos apenas a projetos considerados viáveis, prioritários e financeiramente adequados. O bloqueio da influência política, neste caso, seria o bloqueio de tentativas de aprovar projetos que não se enquadrassem nos critérios estabelecidos pelo Banco e a recusa de pedidos de aprovação de projetos em condições especiais, quer dizer, pulando etapas, por suposta urgência ou prioridade governamental. Neste período, portanto, predomina a ideia de que o BNDES deve obedecer o Estado, podendo contrapor-se a este apenas quando suas requisições não fossem consideradas viáveis, adequadas ou éticas.

\section{III.2.2 Espírito de corpo e competência técnica como estratégias de preservação institucional}

A capacidade de manter critérios rigorosos de análise de projetos, considerada essencial para evitar que a pressão política interfira no funcionamento da instituição é, também no segundo período, atribuída à solidez da estrutura institucional e à qualidade dos quadros da instituição. O recrutamento através de concursos disputados, o treinamento, a integração dos quadros, o cultivo de uma cultura institucional (de valores, de tradições, de ritos) e a adoção de um conjunto de procedimentos operacionais padronizados para análise dos pedidos de financiamento enviados para o Banco são apontados como elementos constitutivos do prestígio e da autonomia operacional da instituição.

A coesão e a solidez institucional, por sua vez, podem ser entendidas como fruto de um forte espírito de corpo gestado ao longo da história do Banco e transmitido no processo de socialização nele vivenciado. O termo "espírito de corpo" designa os sentimentos de afeto, de admiração e de solidariedade entre pares que decorrem da homogeneidade de suas estruturas mentais, ou seja, da comunhão dos esquemas de percepção, de apreciação, de pensamento e de ação de sujeitos cujos inconscientes são bem orquestrados. A adesão ao espírito de corpo, quer dizer, às verdades que fundam a identidade coletiva, constituiria pois o verdadeiro direito de entrada em um determinado grupo (Bourdieu 1989).

A resposta à indagação acerca da existência no Banco de um forte espírito de corpo foi quase sempre positiva. Dentre os principais elementos mobilizados para justificar porque haveria um espírito de corpo na instituição estavam: o tipo de admissão, o plano de carreira, os salários adequados e o ambiente estimulante criado pela convivência com pessoas de alto nível intelectual. Ademais, é ressaltada a comunhão criada pela cultura, pelos valores, pelos ritos e pelo sentido de missão, que dariam origem a um modo BNDense de ser, que estaria no fundamento de um ideal de instituição partilhado pelos funcionários. Malgrado possíveis - ou melhor dizendo, frequentes - discordâncias internas no que se refere às prioridades político-econômicas, prevaleceria uma solidariedade que ajudaria a preservar a instituição, sobretudo em caso de ameaças externas.

"O Banco acopla um concurso para admissão bastante rigoroso [...] a um salário bastante bom, bastante decente. E mais, tem um bom plano de saúde, tem um bom plano de aposentadoria, um bom fundo de pensão. Então, esse conjunto de coisas dá uma certa independência... e, apesar de os funcionários do Banco serem CLT, o Banco tem uma tradição de estabilidade. Não é uma coisa trivial mandar alguém embora. Então essa percepção da estabilidade, acoplada a um bom salário, acoplada a uma dificuldade, uma peneira ou uma filtragem de entrada que é muito efetiva cria um ambiente favorável. Quer dizer, na média, os funcionários do BNDES têm um nível muito bom, um nível intelectual e cultural muito bom e essa percepção de independência em relação ao governo de ocasião ela meio que vai se cristalizando na medida em que o empregado vai ficando

${ }^{35}$ Entrevista. Diretor que mais tempo na casa" ${ }^{\prime 3}$. 
havia sido funcionário de carreira do Banco e que foi diretor no governo PT carreira composta por $62 \%$ Estado, 29\% mercado e 9\% academia. Sem filiação político-partidária.

${ }^{36}$ Entrevista. Especialista convidado para fazer parte da diretoria do Banco no governo PSDB - carreira composta por $26 \%$ Estado, $25 \%$ mercado e $49 \%$ academia. Com filiação político-partidária.
"Tem um forte esprit de corps. São técnicos. Todos se conhecem, se respeitam, trabalharam muito juntos. O BNDES é pequeno, relativamente, concentrado como Banco. Não é uma coisa espalhada do ponto de vista de instituição física [...]. Eu diria que ninguém aceita desvios, internamente. Tem controles recíprocos de colegiados, comitês de crédito, etc. Quer dizer, não pode se meter a besta lá. Entendeu?"’36

"Muito, muito, muito, muito, muito. Isso nós éramos inclusive na cabeça da gente: BNDense. A gente queria aquilo, a gente gostava daquilo, a gente tem nossos ritos processuais. Respeito. Isso é fundamental" ${ }^{37}$.

“O BNDES é uma das instituições que sofre menos ingerência e interferência política. Tem razoável autonomia, isso porque sempre privilegiou a formação de gente de dentro para serem diretores da instituição - em grande parte. E sempre foi uma carreira muito prestigiada também, com formação técnica boa. Eu acho que o BNDES acabou criando essa cultura e esse corpo técnico forte que resistia a algumas interferências" 38 .

\section{III.2.3 Efeito de corpo como resistência à ingerência externa}

${ }^{37}$ Entrevista. Diretor que havia sido cedido por outro órgão público ao Banco e foi diretor no governo PSDB carreira composta por $100 \%$ Estado, $0 \%$ mercado e 0\% academia. Sem filiação político-partidária.

${ }^{38}$ Entrevista. Especialista convidado para fazer parte da diretoria do Banco no governo PSDB - carreira composta por $0 \%$ Estado, $92 \%$ mercado e $8 \%$ academia. Sem filiação político-partidária.
O efeito de corpo, por sua vez, seria a expressão da força dos corpos sobre a sociedade. Quanto mais intenso for o espírito de corpo, maior a capacidade do corpo de imprimir suas orientações no mundo social (Bourdieu 1985, p.73). A forte coesão do corpo de funcionários, a cultura arraigada e o sentido de missão do BNDES são elementos que colaboram para que a instituição possa exercer um forte efeito de corpo, ou seja, para que tenha força para sustentar suas posições contra ameaças externas.

O efeito de corpo é percebido, por alguns dos diretores convidados - ou funcionários políticos - como uma potencial barreira à implementação das diretrizes governamentais. Esses dirigentes mencionam ter tido dificuldade para alterar o curso da instituição que seria, de acordo com eles, muito fechada à introdução de novos princípios, especialmente quando estes diferissem das orientações tradicionais da instituição. Por ter uma cultura, visões de mundo e ideias próprias acerca do desenvolvimento, o Banco dificilmente seria indiferente às decisões governamentais. Quanto mais qualificada uma burocracia, mais dotada de reflexões e orientações gestadas internamente e mais coesa, mais difícil será a tarefa do representante externo de manobrar a máquina para andar em sentidos contrários aos por ela almejados.

"Entrevistador. - Qual considera que deveria ser, na sua opinião, o papel do BNDES na construção, condução de uma política de desenvolvimento?

Entrevistado. - Veja bem, ele devia, para mim, ser menos do que é. Porque a política de desenvolvimento é uma política de governo. O governo é o que foi eleito. Isso é uma política que deve emanar, digamos assim, da autoridade constituída. Vamos supor, vamos considerar que sejam os ministros da Fazenda, do Planejamento e do Desenvolvimento, Indústria e Comércio. Está certo? Então, esses três atores, orientados pelo Presidente da República, têm instrumentos. Quais são os instrumentos? Nós temos o Banco do Brasil, temos a Caixa Econômica, temos o BNDES, temos o BNB, temos o BAZA, temos APEX para a exportação, nós temos os instrumentos. Esses instrumentos são para ser usados, mas, usados por uma política que venha desses atores. Certo? O que é que acontece? Diante da fragilidade institucional da administração direta, e do fortalecimento das estatais, elas passaram a subverter. Então, a política de, energética vem da Eletrobrás, a política de petróleo vinha da Petrobrás, [...] e a política de desenvolvimento vinha do BNDES. [...]. Essa situação mudou bastante. Não sem choro e ranger de dentes [...]. Isso foi absorvido com alguma dificuldade mas eu acho que o BNDES absorveu bem, viu. Hoje ele resiste a uma ou outra política [...]. Eu acho que o BNDES reconhece que ele tem muito a contribuir na elaboração da política mas a elaboração final não é uma atribuição dele BNDES ${ }^{39} "$. 
convidado para fazer parte da diretoria do Banco no governo PT - carreira composta por $26 \%$ Estado, $70 \%$ mercado e $4 \%$ academia. Com filiação político-partidária.

${ }^{40}$ Entrevista. Especialista convidado para fazer parte da diretoria do Banco no governo PSDB - carreira composta por $27 \%$ Estado, $16 \%$ mercado e $57 \%$ academia. Com filiação político-partidária.
${ }^{41}$ Entrevista. Especialista convidado para fazer parte da diretoria do Banco no governo PSDB - carreira composta por $12 \%$ Estado, $37 \%$ mercado e $51 \%$ academia. Com filiação político-partidária.

${ }^{42}$ Schneider (1991 p.50-65) divide o alto escalão do Estado brasileiro em quatro grupos: militares, políticos, técnicos e técnicos-políticos. Seria analiticamente útil diferenciar os técnicos-políticos (cuja origem técnica é seguida de engajamentos políticos) dos políticos-técnicos (políticos com credenciais técnicas). A classificação nativa em "políticos puros" e "políticos técnicos" não revela se a
"Tinha muita resistência. Mas o que acontecia? Você tinha uma resistência não só à privatização, mas toda essa estrutura de enxugamento de funções, por exemplo limitar o tipo de financiamento, para quem que você está financiando... Você tinha pessoas na nossa diretoria mesmo que tinham certa dificuldade, porque vinham do tempo que a política industrial era aquela, de proteção do conteúdo nacional, proteção industrial, subsídio" ${ }^{40}$.

Alguns diretores convidados e com vínculos partidários têm a percepção de que as resistências não se deviam, puramente, à inadequação das propostas do governo aos critérios técnicos defendidos pelo Banco. De acordo com eles, a resposta técnica poderia ser usada como instrumento de resistência política. Quando as ideias próprias do Banco fossem contrariadas pelas políticas governamentais ou pelas decisões da diretoria os técnicos resistiriam: algumas vezes apontando a inadequação do projeto proposto, outras vezes fazendo mais e mais perguntas, ressalvas, objeções, ou simplesmente deixando de engajar-se fortemente na nova diretriz.

Outros entrevistados mencionam que propostas de investimentos em áreas não tradicionalmente apoiadas pelo Banco ou em projetos considerados prioritários pelo governo, ainda que não muito rentáveis, também teriam sofrido resistências por desviarem daquilo que os funcionários considerariam ser atribuição primordial da instituição ou por serem julgados não saudáveis para a preservação/melhora das finanças da casa. Expressões como "apanhar da diretoria", "ter que costurar as políticas", "descer para negociar com os superintendentes", "passar perrengue" para conseguir aprovar algo, foram utilizadas pelos entrevistados para explicar essa situação.

As narrativas indicam, portanto, a existência um complexo processo de negociação interno das políticas contrapondo os funcionários técnicos e os funcionários políticos. Os diretores de carreira, funcionários técnicos em cargos políticos acabariam flutuando entre os dois polos e operando muitas vezes como mediadores nestes conflitos. Comentou-se, nesse sentido, que era importante recrutar diretores da própria casa para conseguir manter diálogo com os funcionários e fazer com que aderissem às prioridades políticas da nova gestão. Caso todos os diretores fossem trazidos de fora, argumentam, a chance de haver resistência aumentava.

"Se você nomeia a diretoria toda nova e tem uma agenda de transformação do Banco. A chance de rejeição era enorme. Para transformar o Banco é preciso ter uma diretoria de gente predominantemente do Banco que entenda a mensagem. Entende? E faça sua a minha mensagem. Então essa foi a minha ideia básica de pegar pessoas de dentro do Banco" ${ }^{41}$.

Os funcionários de carreira, por outro lado, argumentam que não haveria uma resistência à convocação de diretores externos. Estes, todavia, poderiam ser mais ou menos respeitados pela casa dependendo de sua competência técnica e de sua habilidade para gerir a instituição. Um dos entrevistados divide os diretores convidados em dois tipos: os "políticos puros" e os "políticos técni-

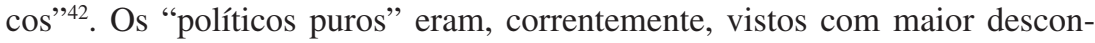
fiança pois duvidava-se de sua competência técnica para entender as tarefas e operações do Banco e temia-se que suas decisões fossem baseadas primordialmente em estratégias de caráter político-partidário desconsiderando qualquer especificidade institucional. Já os "políticos técnicos", ainda que pudessem estar tão comprometidos quanto os "políticos puros" com as diretrizes governamentais, provavelmente seriam recebidos pela casa como legítimos ocupantes de seus postos já que possuíam as credenciais técnicas valorizadas internamente. Mesmo em casos nos quais os funcionários comentam discordar radicalmente de um político considerado técnico, tal discordância não assume a forma de um questionamento do preparo do diretor ou da sua legitimidade para dirigir a casa. Eles podem não aderir às diretrizes do novo diretor mas 
origem primária dos políticos-técnicos é técnica ou política.

43 Entrevista. Especialista convidado fazer parte da diretoria do Banco no governo PT - carreira composta por $26 \%$ Estado, $70 \%$ mercado e $4 \%$ academia. Com filiação político-partidária. respeitam-no porquanto possui a qualificação necessária para ocupar a posição que lhe foi concedida.

O prestígio intelectual, acadêmico e profissional dos diretores técnicos é percebido tanto como um fator de aceitação dentro da casa quanto como um recurso para que o Banco ganhe poder no cenário político nacional. Há uma percepção de que quando os diretores são especialistas de renome e, sobretudo, quando o presidente do Banco é uma figura conhecida e respeitada, a chance de que o BNDES tenha seus planos e políticas acatados pela administração central aumenta.

"Agora, óbvio, pela, pela capacidade do [nome de um diretor], pela respeitabilidade que ele tem, obviamente quando ele bota uma proposta na mesa essa proposta ganha um peso extraordinário. Tá certo? Mas eu acho que isso é sadio. Ou seja, você ser um operador de uma política mas pela sua competência a sua opinião sobre essa política vale tanto que eventualmente você tem um poder extraordinário para influenciar a decisão dela"43.

Se há uma percepção de que o Banco teria perdido sua autonomia para desenhar diretamente as políticas, a indicação para a direção do Banco de um dirigente de alto prestígio pode funcionar como um elemento de valorização e empoderamento da instituição. Acredita-se que uma diretoria forte aumentaria a chance de que as ideias e formulações políticas do BNDES ecoassem pelo sistema e conseguissem a adesão dos responsáveis políticos titulares pela tomada de decisão final.

\section{III.2.4 O caráter racional da técnica em contraposição à irracionalidade da política}

A partir da observação dos discursos recolhidos nas entrevistas constata-se que os termos "técnico" e "político" continuam a se opor no período atual. Os critérios empregados para que alguém seja chamado de técnico ou de político, entretanto, não são, necessariamente, objetivos e mesuráveis. É possível que dois sujeitos com qualificação acadêmica e profissional semelhante sejam classificados distintamente um como "técnico" e o outro como "político". É necessário, portanto, explorar os possíveis sentidos da atribuição de um ou outro rótulo.

É possível argumentar que, em um órgão de Estado que calca sua excelência na capacidade de produzir conhecimento econômico e de dirigir sua ação de maneira técnica, a frase "aquele sujeito é um político" embute uma apreciação negativa que sinaliza a existência de uma incompatibilidade daquela pessoa com o ideal do Banco como uma instituição cuja excelência e neutralidade seria garantida pela qualidade técnica. "Aquele sujeito é um político" ou "existiam grupos ideológicos" são caracterizações que, direcionadas a dirigentes e grupos inequivocamente dotados qualificação técnico-científica e de credenciais acadêmico-profissionais, funcionam, primordialmente, como forma de desqualificação de oponentes de natureza política.

Os termos política e político adquirem facilmente o caráter de injúria pois decorrem de uma polaridade disseminada e respaldada no imaginário nacional.

"Esse raciocínio - até hoje vigente em discursos da elite ilustrada e em falas do senso comum da população brasileira - estabelece uma dicotomia 'natural' entre políticos e técnicos. Por essa dicotomia, a despeito da importância e do tamanho do aparelho de Estado no Brasil - ou talvez por isso mesmo - os políticos são identificados como 'profissionais da Política' avessos à realidade nacional, quer por falta de preparo, quer por falta de caráter. Em oposição a eles, constrói-se a figura do 'técnico', do 'administrador' que, por sua formação específica de alto nível, por seu 'isolamento' da política e por sua 'neutralidade', é capaz de romper com o 'atraso' e criar riqueza. Ou seja, se nosso mal é político, sua solução reside, com frequência, na criação de uma administração que resolva 
problemas basicamente sócio-econômicos, o que requer um 'saber técnico', definido ao mesmo tempo e de forma interativa como um saber especializado e despolitizado" (Gomes 1994, pp.1-2).

Seria preciso, então, que se pensasse o que afinal é fazer política e em que medida uma atuação burocrática qualquer poderia ser considerada não política. Weber define uma questão como política quando nela estão em disputa interesses de poder. Os políticos, por sua vez, seriam aqueles que se envolveriam com paixão nas causas que elegessem e que disputariam poder e prestígio.

Quando se observa a atuação de uma burocracia estruturada, é difícil dizer que ela não seja movida por causas e paixões. Ainda que seus técnicos abdiquem da atuação na política profissional, eles não aceitam que se deixe aos ditos políticos a decisão sobre os rumos da política em sua área de competência. Eles defendem com afinco ideais que os colocam, frequentemente, em conflito com os representantes políticos aos quais deveriam submeter-se. Tampouco está fora do âmbito burocrático a disputa por poder e prestígio. Diferentemente da concepção de Weber, segundo a qual o prestígio do funcionário seria proporcional à sua capacidade de não imiscuir-se na política, o que prevalece é a atribuição de prestígio àqueles que conseguem fazer de suas opções políticas decisões de natureza técnica. Quer dizer, aos que têm o poder de convencer os políticos eleitos a engajarem-se em determinadas políticas que, por serem apresentadas como as mais adequadas e racionais quando avaliadas de acordo com critérios técnico-científicos, não são interpretadas como políticas e sim como meras alternativas técnicas.

Se há um jogo para que a instituição ganhe influência sobre o cenário nacional, se certas políticas são barradas pela burocracia e se existem visões de desenvolvimento concorrentes no interior da instituição - como revelam os depoimentos - as tomadas de decisão da burocracia não podem ser desvinculadas das perspectivas políticas concorrentes, cabendo, assim, indagar em que medida as escolhas cotidianas dos especialistas em economia poderiam estar isentas de orientações de natureza política.

Conceder empréstimos uma ou outra comunidade, destinar verba para a restauração de um patrimônio em detrimento de outro, acreditar que um tipo de indústria trará mais crescimento para o país do que outras, financiar microcrédito ou fusões e aquisições, privilegiar o território nacional ou financiar investimentos em outros países, são escolhas necessariamente atreladas a visões de política social e política econômica, que promovem uma forma específica de distribuição - entre muitas possíveis - dos recursos materiais e de poder entre agentes e grupos sociais. Ainda que absolutamente todas essas decisões fossem tomadas pelos políticos profissionais e não pelos funcionários de carreira e dirigentes do Banco, é possível indagar se a própria concepção e escolha das ferramentas, procedimentos e critérios de avaliação ditos técnicos não germinariam de visões de economia derivadas de orientações políticas e visões de país e de mundo específicas.

O feito de que a desvalorização do político em contraposição ao técnico seja convergente com o senso comum é um trunfo poderoso de neutralização da ação política dos técnicos. A crença na racionalidade da ciência, da técnica e das formas de gestão modernas acabaria por proteger as escolhas apresentadas como técnicas da crítica, impedindo que os fundamentos da ciência e da técnica e as finalidades que movem a ação dos técnicos fossem julgadas em suas dimensões políticas, ou seja, em sua irracionalidade. 


\section{A ilusão da política como ação técnica de especialistas}

Os questionamentos que Pierre Bourdieu e Herbert Marcuse dirigiram ao ideal weberiano de burocracia sin ira ac studio podem oferecer elementos para discutir criticamente os sentidos e efeitos do emprego dos termos técnica e política nos depoimentos e entrevistas.

Pierre Bourdieu, em La Noblesse d'État, define, seguindo Max Weber, as burocracias como estruturas de dominação cuja legitimidade advém da competência técnica para a administração racional e, tal qual Weber, destaca o papel dos títulos e dos exames no recrutamento para os corpos burocráticos. Todavia, se Weber considera que a seleção de especialistas para os cargos burocráticos contribuiria para excluir a irracionalidade e os sentimentos da administração pública, aumentando a sua eficiência, Bourdieu argumenta que a eleição dessa "classe universal" modernizadora não seria imperativamente lógica. Ela decorreria de "um conjunto bem sucedido de atos mágicos" capazes de mascarar os inúmeros fundamentos não racionais e arbitrários da escolha dos "homens competentes". Os diplomas dos especialistas concorreriam, pois, para recobrir magicamente e ocultar tantas outras competências sociais, culturais, estilísticas e simbólicas, partilhadas pelas elites e requeridas para alcançar as posições sociais de poder e prestígio. Competências estas que precedem e largamente ultrapassam o treinamento propriamente técnico (Bourdieu 1989, p.537).

A ilusão tecnocrática que decorre da atribuição de uma racionalidade técnica aos especialistas contribui, ademais, para apagar as marcas sociais de suas tomadas de posição. Informadas pelas visões de mundo vigentes nos espaços em que foram socializados, na família, na escola, na vida mundana, as tomadas de decisão estão vinculadas, necessariamente, à posição por eles ocupada no espaço social, não sendo, portanto, universais. A apresentação das decisões dos técnicos como racionais, neutras, técnicas e eficazes, ou seja, a conversão de suas crenças e de sua visão de mundo em princípios universais, seria, assim, um mecanismo de reforço e legitimação da dominação, quer dizer, de reprodução da distribuição desigual de recursos, inclusive do próprio poder (idem, pp.163-167, pp.555-558).

Se, de um lado, Pierre Bourdieu faz notar que a ilusão gerada pela especialização dos quadros burocráticos opera no sentido de legitimar a dominação de um grupo social específico ao apresentá-lo como o mais preparado para o exercer o poder de modo racional e neutro, de outro, Herbert Marcuse permite questionar a neutralidade da própria técnica, que julga ser indissociável da lógica de política vigente na sociedade que a ela dá origem.

Em sua conferência Industrialização e Capitalismo na obra de Max Weber, Herbert Marcuse afirma existirem elos entre o desenvolvimento da razão formal: abstrata, metódica, sistemática e matemática, que se estabelece progressivamente como forma predominante de razão na ciência e na burocracia científico-especializada e a racionalidade econômica do próprio capitalismo, que converte a eficiência - quer dizer, a comparação de quantidades desprovidas de qualidades - no único parâmetro de julgamento da razão (Marcuse 1998, pp.116-117).

As ciências, as técnicas e os instrumentos não são, pois, formas universais e socialmente desenraizadas. Elas não compõem um conjunto de ferramentas intercambiáveis disponíveis para que se ajuste de modo eficaz os meios aos

${ }^{44}$ Em Theodor Adorno e Max Horkheimer prevalece a crítica à maneira como, no mundo em processo de desencantamento descrito por Max Weber, a racionalização levou à irrazão fins $^{44}$. Ferramentas neutras que poderiam ser igualmente empregadas com objetivos bons ou nefastos, conforme os valores prevalecentes - como pretende o positivismo ${ }^{45}$. As técnicas, argumenta, são dispositivos que trazem gravados em si o projeto sócio-histórico, a racionalidade político-material e os interesses dominantes da sociedade na qual foram gestadas. A razão política estaria, 
ao dissociar, como defendia o próprio Weber, a racionalidade em relação aos meios da reflexão racional sobre os fins, aos renunciar à tarefa de discriminar as finalidades perseguidas pelos sujeitos (Horkheimer 2000, p.16).

${ }^{45}$ De acordo com as premissas positivistas, a ciência deveria ater-se aos fatos para proteger-se o da contaminação a superstição e de permitir que, com auxílio das faculdades de classificação e calculabilidade e dos métodos e técnicas científicos, os indivíduos pudessem agir de maneira exata e racional e ampliar o seu controle sobre a natureza (Adorno \& Horkheimer 1985, p.100, pp.162-163, p.33).

${ }^{46}$ A premissa de que a técnica seria politicamente determinada não é tecnofóbica na medida em que, ao conceber a existência de uma pluralidade de racionalidades técnicas considera-se que a tecnologia e a própria ciência poderiam mudar em consonância com o contexto social no qual são desenvolvidas, podendo ser em outros cenários libertadoras (Feenberg 1996, p.3; Marcuse 1967, pp.160-162).

\footnotetext{
${ }^{47}$ Michel Callon faz notar que existe em língua inglesa uma diferença entre os termos economics (a Ciência Econômica) e economy (a economia como atividade prática), e sustenta que a Ciência Econômica não se limita a representar a economia, ou seja, a descobrir suas leis; ao contrário, ela também molda e formata a
}

portanto, contida na própria técnica e não poderia ser dela desvinculada. Transformar a sociedade implicaria, assim, na tarefa de criar outras técnicas adequadas aos objetivos da nova formação social ${ }^{46}$ (idem, pp.125-127, p.132).

Se, por um lado, Marcuse busca situar as ciências e as técnicas no processo sócio-histórico, por outro, argumenta que a própria burocracia científico-especializada - "cuja racionalidade organiza e controla coisas e homens, fábricas e burocracia de funcionários, trabalho e tempo livre" (idem, pp.115-116) - é uma formação social particular cujas raízes encontram-se precisamente no processo de racionalização narrado pelo próprio Max Weber. A ilusão burocrática, portanto, serviria ao capitalismo que a gestou e suas técnicas seriam, consequentemente, formas de empreender a reprodução da dominação dos homens, mulheres e da natureza própria a esse sistema.

Os elementos da crítica à política feita em nome da técnica que podem ser extraídos das reflexões apresentadas e aplicados ao caso analisado são, portanto:

(i) Uma crítica à burocracia como portadora de uma racionalidade universal posto ser ela, de um lado, um arranjo organizacional gestado em uma sociedade com uma razão política específica e, de outro, uma estrutura formada por uma população localizada em pontos determinados dos espaço social aos quais correspondem princípios de visão e divisão social particulares e interessados.

(ii) Uma ruptura com a noção de neutralidade e universalidade da própria técnica, da qual decorre, logicamente, a asserção de que, mesmo que os aplicadores da técnica fossem perfeitamente amorfos, os efeitos de sua aplicação não seriam desprovidos de direcionamento político, posto que ela encarnaria a lógica da razão histórica em meio à qual foi formada.

Dentre os domínios nos quais a ciência e a técnica foram convocadas a servir e legitimar decisões diretamente políticas, talvez o mais proeminente seja a "Ciência" Econômica. A Ciência Econômica, coerentemente com a interpretação marcusiana, embute - mais visivelmente do que tantas outras ciências - uma serie de princípios normativos próprios ao momento e ao local em que foi concebida que se enraízam no fundamento da própria disciplina.

Primeiramente, ela é presidida pela lógica da eficiência medida em termos puramente quantitativos, cuja gênese estaria na própria instituição da forma mercadoria e na abstração da qualidade dos produtos que permite a comensurabilidade e a troca (Marx 1983, p.55). A abstração calculável dos produtos é acompanhada por uma noção de homem abstrato com preferências dadas cuja ação pode ser prevista e calculada. Em segundo lugar, concebida inicialmente como Economia Política, a Ciência Econômica molda-se na razão de Estado moderna, assumindo dela o imperativo de expansão e multiplicação de poderes e recursos. Os especialistas em economia são doravante encarregados do controle das contas nacionais, do diagnóstico das tendências econômicas e da elaboração de planos de investimento e desenvolvimento para os Estados (Elias 2006, p.170).

A capacidade da Ciência Econômica de performar ${ }^{47}$ a realidade decorre da generalização da crença em seu caráter racional, em sua capacidade de calcular e de fazer recomendações cientificamente orientadas. A crescente matematização da economia e a apresentação desta como uma ciência com critérios e instâncias próprias de consagração colaboram para que se cristalize o revestimento neutro-universal que legitima as ações conduzidas com base nos ditames da Ciência Econômica. A prevalência atual da nomenclatura da Ciência Econômica em detrimento da precedente Economia Política adensa a ocultação das finalidades políticas subjacentes a essa ciência aplicada. 
economia com seus enunciados (Callon 1998, pp.1-2).

\section{Conclusões}

48 O Conselho Nacional de Política Industrial e Comercial (1944), a Comissão do Planejamento Econômico (1944), a SUMOC (1945), a Comissão Mista

Brasil-Estados Unidos (1950), a Assessoria Econômica da Presidência da República (1951), o BNDE (1952) e a SUDENE (1959) são criados e se somam aos já existentes BB (1808) e à Divisão de Estudos Econômicos e Financeiros do Ministério da Fazenda (1934).
A consagração da Economia como ciência está na raiz da crença na aptidão dos economistas para formatar a economia à luz de suas análises, modelos e predições (Callon 1998). O expert em economia é convocado a empregar sua capacidade de calcular, prever e planejar para ajustar meios e fins de modo a obter a maior eficiência possível no emprego dos recursos escassos. Investidos do poder de tomar decisões políticas como se fossem técnicas, de empregar ferramentas particulares como se fossem universais e de deslocar aqueles cujas orientações políticas não se fazem recobrir pela neutralidade, os economistas acumulam poder e espalham-se pelos múltiplos órgãos encarregados da gestão e do planejamento econômico (Loureiro 1997, p.71; Lebaron 2000, p.99).

A oposição entre técnica e política, técnicos e políticos no primeiro período analisado pode ser interpretada como parte do movimento de ascensão dos especialistas em economia e do conquista dos cargos de direção dos organismos econômicos, que era acompanhado da deslegitimação e deslocamento daqueles que não possuíam credenciais especializadas para conduzir a política. Tal processo ocorre no momento em que o campo da Ciência Econômica no Brasil está em implementação, sendo um período no qual as instituições econômicas do país se multiplicam rapidamente ${ }^{48}$.

Os questionamentos tecidos por Pierre Bourdieu direcionam a análise para a observação características sociais desses especialistas que estariam na raiz de seu poder e que ajudariam a explicar quais as visões de mundo presidem suas tomadas de posição: porque estes e não outros indivíduos foram capazes de adquirir as raras credenciais oferecidas pelas instituições universitárias? Quais as suas origens? Quais os seus trunfos? Que visões de mundo adquiriram ao longo de seus percursos pelo espaço social? Tais indagações ajudariam a desarticular a ideia de que os burocratas seriam abstratos poderiam agir descolados de suas posições sociais promovendo políticas neutras e universais, ao contrário das políticas interessadas e irracionais definidas pelos políticos.

Nesse primeiro período os funcionários e dirigentes não negavam que estivessem fazendo política - racionalmente, é claro! - que tivessem ideais e que tentassem promovê-los junto ao governo e à sociedade. No período seguinte, ainda que a questão da política de governo versus política de Estado seja repetidamente mencionada, que se fale ainda em formulação de política e que sejam mencionadas algumas discordâncias em relação ao governo, a maioria dos entrevistados argumenta que o BNDES é uma instituição técnica e eficiente que age de acordo com as diretrizes definidas por cada governo. Em linhas gerais dizem: é para fazer privatização? Faremos, e bem feito! É para fazer indústria básica? Faremos com eficácia! É para fazer política social? Faremos também!

Nesse contexto mobilizar a crítica de Marcuse ajuda a adicionar a seguinte reflexão: ainda que os objetivos de todas as ações do BNDES fossem traçados pelo governo, ou seja, as finalidades tivessem sido inteiramente definidas na esfera pública, não estando ao alcance da subjetividade igualmente determinada dos burocratas, isto é, ainda que o Banco somente se encarregasse de ajustar os fins aos meios, seria a ação de seus técnicos neutra e universal? A resposta marcusiana seria negativa, pois se as lógicas políticas e os valores vigentes residem na essência das teorias e técnicas às quais dão origem, a escolha da técnica seria inexoravelmente política já que indissociável da eleição do conjunto de valores a ela subjacentes.

É possível concluir com a sugestão de que a ilusão tecnocrática é antes de tudo uma ilusão à qual entregam-se os próprios tecnocratas que por meio dela 
conquistaram seu lugar no campo do poder e nele se reproduzem (Bourdieu 1989, p.167). A incorporação em seus discursos cotidianos da polaridade presente no senso comum - que aparta a técnica e a política - expressa quão enraizada está a crença na racionalidade como princípio de ordenação e legitimação da dominação baseada no conhecimento dito técnico-científico em uma sociedade, para voltar ao ponto de partida weberiano, desencantada.

Elisa Klüger (elisa.kluger@gmail.com) é bacharel em Relações Internacionais pela Universidade de São Paulo (USP). Atualmente é aluna de doutorado do Programa de Pós-Graduação em Sociologia na Universidade de São Paulo, tendo sido Visiting Research Student na University of California - Berkeley e na Universtité de Picardie Jules Verne. Afiliação Institucional: Universidade de São Paulo, São Paulo, SP, Brasil.

\section{Referências}

Adorno, T. \& Horkheimer, M., 1985. Dialética do esclarecimento: fragmentos filosóficos. Rio de Janeiro: Zahar Editores.

Almeida, R., 2009. Entrevista concedida a Ângela Coronel, Aloísio Barbosa de Araújo e Rui Modenesi em 15 de julho de 1982. Memórias do Desenvolvimento, 3(3). Rio de Janeiro: Centro Internacional Celso Furtado de Políticas para o Desenvolvimento, pp. 193-208.

Bourdieu, P., 1985. Effet de champ et effet de corps. Actes de la Recherche en Sciences Sociales, 59, p.73. 1989. La noblesse d'état: grandes écoles et esprit de corps. Paris: Les éditions de Minuit.

Callon, M., 1998. Introduction: The Embeddedness of Economic Markets in Economics. In ed. The Laws of the Markets. Oxford: Blackwel.

Campos, R., 2009. Entrevista concedida a Ângela Coronel, Euclydes Pereira, Aloísio Barbosa de Araújo e Roberto Rodrigues em 27 de março de 1982. Memórias do Desenvolvimento, 3(3). Rio de Janeiro: Centro Internacional Celso Furtado de Políticas para o Desenvolvimento, pp. 41-64.

Cohn, G., 1979. Crítica e Resignação: fundamentos da sociologia de Max Weber. São Paulo: T. A. Queiros Editor.

D’Araujo, M.C.S., 1992. O segundo Governo Vargas 1951-1954: democracia, partidos e crise política. São Paulo: Ática.

Elias, N., 2006. Sobre a sociogênese da economia e da sociologia. In Escritos e Ensaios. V. 1: Estado, processo, opinião pública. Rio de Janeiro: Zahar Editores.

Evans, P., 1995. Embedded Autonomy: States and Industrial Transformation. New Jersey: Princeton University Press.

Feenberg, A., 1996. Marcuse ou Habermas: duas críticas da tecnologia. Digit. Original disponível em: Marcuse or Habermas: Two Critiques of Technology. Inquiry, 39(1), pp. 45-70.

Furtado, C., 1997. Obra autobiográfica de Celso Furtado. V. 1. Rio de Janeiro: Paz e Terra. , 2009. Entrevista concedida a Nora Lanari, Ângela Coronel, Rui Modenesi, Aloísio Barbosa e Roberto Rodrigues em 22 de junho de 1982. Memórias do Desenvolvimento, 3(3). Rio de Janeiro: Centro Internacional Celso Furtado de Políticas para o Desenvolvimento, pp.101-122.

Geddes, B., 1990. Building "State" Autonomy in Brazil. Comparative Politics, 22(2), pp.217-235.

Gomes, A.C., ed. 1994. Engenheiros e economistas: novas elites burocráticas. Rio de Janeiro: Editora Fundação Getúlio Vargas.

Gouvêa, G.P., 1994. Burocracia e elites burocráticas no Brasil. São Paulo: Paulicéia.

Horkheimer, M., 2000. Eclipse da razão. São Paulo: Centauro.

Klüger, E., 2014. Técnicos e políticos nos primeiros anos do BNDE. Cadernos do Desenvolvimento, 9(14), pp.59-81.

Lebaron, F., 2000. La Croyance Économique: les économistes entre science et politique. Paris: Éditions du Seuil.

Lopes, L. 2009. Entrevista concedida a Ângela Coronel, Ricardo Weiss, Marcelo Averbug e Iolanda em 8 de março de 1982. Memórias do Desenvolvimento, 3(3). Rio de Janeiro: Centro Internacional Celso Furtado de Políticas para o Desenvolvimento, pp.9-40.

Loureiro, M.R., ed. 1997. 50 anos de Ciência Econômica no Brasil: pensamentos instituições, depoimentos. Petrópolis: Vozes.

Loureiro, M.R.; Abrucio, F.L., 1998. Burocracia e política na nova ordem democrática brasileira: o provimento de cargos no alto escalão do governo federal (governos Sarney, Collor, Itamar Franco e FHC). Relatório de pesquisa. Núcleo de Pesquisas e Publicações - EAESP/FGV.

Marcuse, H., 1967. A ideologia da sociedade industrial. Rio de Janeiro: Zahar Editores. 1998. Industrialização e Capitalismo na obra de Max Weber. In Cultura e Sociedade. V. 2. São Paulo: Editora Paz e Terra.

Marx, K., 1983. O Capital: crítica da economia política. São Paulo: Abril Cultural.

Martins, L., 1985. Estado capitalista e burocracia no Brasil pós-64. Rio de Janeiro: Paz e Terra.

Motta, M.S., 2005. Os "Boêmios Cívicos" da Assessoria Econômica: saber técnico e decisão política no governo Vargas (1951-54). In VI Encontro Regional no Sudeste de História Oral da ANPUH. Juiz de Fora (MG).

Nunes, E.O., 1984. Bureaucratic Insulation and Clientelism in Contemporary Brazil: Uneven State-building and the Taming of Modernity. Tese de Doutorado. Berkeley: University of California.

Olivieri, C., 2007. Política, burocracia e redes sociais: as nomeações para o alto escalão do Banco Central do Brasil. Revista Sociologia e Política, 29, pp.147-168. 
2011. Os controles políticos sobre a burocracia. Revista de Administração Pública, 35(5), pp.1395-1424.

Osório, J. 2009. Entrevista concedida a Ângela Coronel e Luiz Carlos em 10 de fevereiro de 1982. Memórias do Desenvolvimento, 3(3). Rio de Janeiro: Centro Internacional Celso Furtado de Políticas para o Desenvolvimento, pp.137-160.

Schneider, B.R., 1991. Politics within the State: Elite Bureaucrats and Industrial Policy in Authoritarian Brazil. Pittsburgh: Pittsburgh University Press.

Soares, S.J.M., 2009. Entrevista concedida a Ângela Coronel e Salo Coifman em 6 de maio de 1982. Memórias do Desenvolvimento, 3(3). Rio de Janeiro: Centro Internacional Celso Furtado de Políticas para o Desenvolvimento, pp.209-241.

Tavares, M.C., 2009. Entrevista concedida a Nora Lanari, Ângela Coronel, Salo Coifman, Rui Modenesi, José Eduardo Pereira de Carvalho, Marcelo Averbug em 6 de maio de 1982. Memórias do Desenvolvimento, 3(3). Rio de Janeiro: Centro Internacional Celso Furtado de Políticas para o Desenvolvimento, pp. 161-192.

Vianna, M.P., 2009. Entrevista concedida a Ângela Coronel, Ricardo Weiss e Marcelo Aveburg em 18 de fevereiro de 1982. Memórias do Desenvolvimento, 3(3). Rio de Janeiro: Centro Internacional Celso Furtado de Políticas para o Desenvolvimento, pp.65-98,

Weber, M., 2004a. Economia e Sociedade: fundamentos da sociologia compreensiva. V. 1. Brasília: Editora UNB. 2004b. Economia e Sociedade: fundamentos da sociologia compreensiva. V. 2. Brasília: Editora UNB. 2011. Ciência e Política: duas vocações. São Paulo: Cultrix Editora.

\title{
Outras fontes
}

BNDES. 2002. Estatuto do BNDES. Disponível em: http://www.bndes.gov.br/SiteBNDES/bndes/bndes_pt/Institucional/O_BNDES/Legislacao/estatuto_bndes.html. Acesso em: 6 jul. 2015.

Centro Celso Furtado, 2009. Memórias do Desenvolvimento, 3(3). Rio de Janeiro: Centro Internacional Celso Furtado de Políticas para o Desenvolvimento.

\begin{abstract}
This article makes a comparative analysis of the contradictions between the notions of technical and political in the speeches of the directors and staff of the Brazilian National Bank for Economic and Social Development BNDE(S) in two periods: from 1952 to the early 1970s and from 1994 to 2011. The data used to establish this comparison was extracted from a set of interviews conducted in the 1980s with people that worked at the bank during the first period, and a second set of interviews made between 2012 and 2014 , with those who were directors of the BNDES in the second period. The analysis shows that there is a transition in the modal pattern of the speeches. Initially the bureaucracy would oppose to the politicians, claiming that they were more qualified than the politicians to make political and economic decisions. In the second period, after returning to a democratic regime, the discourse expressed the tension generated by the simultaneous need to respond to the current democratic govern and the necessity of preserving the values, the historical mission of the BNDES and its technical excellence against political interference. In this second period, the legitimacy of the bureaucrats and of their decisions comes not only from their personal qualification, but above all from the refinement of the techniques employed by them to make political-economic choices. The oppositions found were analyzed according to the critical theories of Pierre Bourdieu and Herbert Marcuse, which allow us to question the meritocratic nature of the economic experts and the neutrality of the science and the techniques employed by them. The article contributes to the study of the relationship between politics and bureaucracy in Brazil through the study of a paradigmatic case that allow us to verify how the relation between the sphere of technique-science and the sphere of politics changed over time and to search for the social foundations of this transformation.
\end{abstract}

KEYWORDS: BNDES; technique; politics; Pierre Bourdieu; Herbert Marcuse.

License information: This is an open-access article distributed under the terms of the Creative Commons Attribution License (CC-BY-NC 4.0), which permits unrestricted use, distribution, and reproduction in any medium, provided the original work is properly cited. 